\title{
Direct Deoxygenation of Aryl Ketones Using Gallium(III) Chloride and Chlorodimethylsilane
}

\author{
Jaewoo Choi and Yonghan Kang"

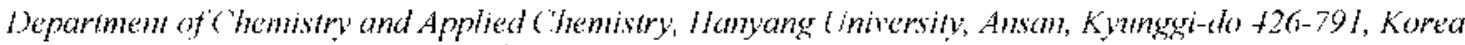 \\ "L-mail: whmkang@ @hanyamg.ac. $k r$ \\ Received october 25, 2004
}

Key Words : Direct deoxygenation, Gallium(III) chloride. Chlorodimethylsilane

Generally, reduction of the carbonyl group of aldelyde and ketone to the corresponding methylene derivative can be carricd out by chemical methods such as Clemmensen reduction, ${ }^{1}$ Wolff-Kishner reduction, ${ }^{2} \mathrm{LiAll} \mathrm{H}_{4}-\mathrm{AIC} \mathrm{I}_{3},{ }^{3} \mathrm{NaBI} \mathrm{L}_{-}$ $\mathrm{CF}_{3} \mathrm{CO}_{2} \mathrm{H}_{7}{ }^{1} \mathrm{Fl}_{3} \mathrm{SiH}-\mathrm{BF}_{3}$ or $\mathrm{CF}_{3} \mathrm{CO}_{2} \mathrm{H}^{5-7} \mathrm{HI}-\mathrm{Ph}_{1}$ osphorus ${ }^{\left.\mathrm{x}^{4}\right)}$ or by catalytic hydrogenation. ${ }^{10}$ However, because of their harsh conditions or requirement of using stoichiometric or excess amount of lewis acid, many of these melhods ate restricled from the use for compounds containing other functional groups. Recently the combination of a catalytic amount of $\mathrm{InCl}_{3}$ and 2 equivalent of $\mathrm{Mc}_{2} \mathrm{SiClH}$ is reported 10 be quite effeclive for deoxygenation of aryl ketones to the corresponding hydrocarbons under mild conditions. ${ }^{1]}$ The combination of hydride donor and I.cwis acid was reported as useful synthetic method for the reductive Friedel-Craft alkylation of aromatic compounds with various ketones via carbocation intermediate. ${ }^{12}$ Direct deoxygenation of ketones was carricd out by the reaction of carbocation interincdiate with hydride.

Elements which belong to the same group in the Periodic able revealed the same clicmical reaclivity. We paid attention to the reactivity of gallium which belongs to the same group as boron, aluminum, and indium. However, there had becn only few examples of synthetic reaction using gallium compounds. ${ }^{1.14}$ In this paper, we report on the gallium(III) chloride-mediated direct deoxygenation of aryl ketones with chlorodimethylsilane as a hydride donor:

The analogous reductions of aryl kelones to the corresponding methylenes by using chlorodimethylsilane with gallium(IlJ) chloride as I cwis acid instead of indium(III) chloride were invesligaled.

General procedure is as the following. Gallitum(III) chloride was dissolved in $\mathrm{CH}_{2} \mathrm{Cl}_{2}$ dried over $\mathrm{CaCl}_{2}$ to prepare a $0.1 \mathrm{M}$ solulion. Aryl ketone $(2.0 \mathrm{mmol})$ in $\mathrm{CH}_{2} \mathrm{Cl}_{2}$ ( $\mathrm{l} \mathrm{mL}$ ) was added dropwise to a mixture of gallium(III) chloride ( 1 or $5 \mathrm{~mol} \%$ ) and cllorodimethylsilane $(4.8 \mathrm{mmol}$ ) in $\mathrm{CH}_{2} \mathrm{Cl}_{2}(2 \mathrm{mI}$.) at ambient temperalure under nitrogen atmosphere. In some cases, ayyl ketone was added dropwise under ice cooling (Table l). Alter completion of the reaction, the reaction mixture was washed with water. The organic layer was separated and dried over $\mathrm{MgSO}_{4}$. The filtrate was evaporated to the dryness. The yield of desired product was acquired by GC analysis $[25 \mathrm{~m}$ OV-170/ silica capillary column, temperature programmed $50^{\circ} \mathrm{C}$ ( $(1$ min hold) to 280
"C. (3 min hold) at a rate of $25^{\circ} \mathrm{C} / \mathrm{min}$, helium flow rate 30 $\mathrm{mI} / \mathrm{min}]$ and the structure of isolated product was conlimed by ${ }^{1} \mathrm{H}$ NMR spectrum.

Linder the above conditions direct deoxygenation reactions of various carbonyl compounds wilh gallium(III) chloride and chlorodimellylsilane were carried out. The obtained results are as shown in Table 1.

In accordance with the proposal by $\Lambda$ kio Baba and his coworkers," a plausible mochanism is shown in Scheme 1, which has three steps; lydrosilylation of carbonyl group, gencration of the carbocation by desiloxylation, and reaction of carbocation with hydride derived from excess chlorodi-

Table 1. Direct deoxygenation of various aryl ketones using the combination of chlorodimethylsilane and gallium(lli) chloride

\begin{tabular}{|c|c|c|c|c|c|c|c|}
\hline & & $1 a-r$ & $\mathrm{CH}_{2} \mathrm{Cl}_{2}$, it & & & 2a-r & \\
\hline Run & & $\mathrm{R}$ & $\mathrm{Y}$ & $\begin{array}{l}\text { Reaction } \\
\text { Temp }\end{array}$ & $\begin{array}{l}\text { Timed } \\
\text { minn }\end{array}$ & \multicolumn{2}{|c|}{ Yield $\%$} \\
\hline 1 & 1:a & $\mathrm{CH}_{3}$ & $\mathrm{H}$ & $0^{\circ} \mathrm{C}$ & 10 & $2 a$ & 99 \\
\hline 2 & lb & $\mathrm{Cl}_{2} \mathrm{CII}_{3}$ & II & $0^{\circ} \mathrm{C}$ & 10 & $2 b$ & 94 \\
\hline 3 & 1c & $\mathrm{CH}_{2} \mathrm{CH}_{2} \mathrm{CH}_{3}$ & $\mathrm{H}$ & $0^{\circ} \mathrm{C}$ & 10 & $2 c$ & 79 \\
\hline 4 & 1d & $\mathrm{CH}\left(\mathrm{CH}_{3}\right)_{2}$ & $\mathrm{H}$ & $\pi$ & 10 & $2 d$ & 75 \\
\hline $5^{: 1}$ & 1e & $\mathrm{Ph}$ & II & it & 30 & $2 e$ & 64 \\
\hline 6 & 1f & $\mathrm{CH}_{3}$ & $o-\mathrm{Ph}$ & $0^{\circ} \mathrm{C}$ & 10 & $2 f$ & 72 \\
\hline 7 & 1g & $\mathrm{CH}_{3}$ & $m-O C \mathrm{H}_{3}$ & $\pi$ & 5 & $2 \mathrm{~h}$ & $-b$ \\
\hline 8 & Ih & $\mathrm{CH}_{3}$ & $p-O C l 1_{3}$ & it & 60 & $2 g$ & 95 \\
\hline 9 & $1 \mathrm{i}$ & $\mathrm{CH}_{3}$ & $m-\mathrm{NO}_{2}$ & $0^{\circ} \mathrm{C}$ & 10 & $2 \mathbf{j}$ & $37 \%$ \\
\hline $10^{i}$ & $1 \mathbf{j}$ & $\mathrm{CH}_{3}$ & $p-\mathrm{NO}_{2}$ & $0^{\circ} \mathrm{C}$ & 10 & $2 \mathbf{i}$ & $37^{i}$ \\
\hline II & $1 k$ & $\mathrm{CH}_{3}$ & $m-\mathrm{NH}_{2}$ & $\mathrm{rt}$ & - & \multicolumn{2}{|c|}{ No reaction } \\
\hline 12 & $1 \mathrm{~m}$ & $\mathrm{CH}_{3}$ & $p-\mathrm{NH}_{2}$ & rt & - & \multicolumn{2}{|c|}{ No reaction } \\
\hline 13 & $1 n$ & $\mathrm{CH}_{3}$ & $p-\mathrm{CH}_{3}$ & rt & 10 & $2 n$ & 62 \\
\hline 14 & 10 & $\mathrm{CH}_{3}$ & $\mu-\mathrm{Br}$ & $0^{\circ} \mathrm{C}$ & 10 & 20 & 82 \\
\hline $15^{\prime \prime}$ & $1 p$ & \multicolumn{2}{|c|}{$\begin{array}{l}\text { 3,4-Dihydro-1 }(2 H) \text { - } \\
\text { naphithalenone }\end{array}$} & rt & 60 & $2 p$ & 78 \\
\hline 16 & $1 q$ & \multicolumn{2}{|c|}{ Methyl I-naphthyl ketone } & $0^{\circ} \mathrm{C}$ & 10 & $2 q$ & 90 \\
\hline 17 & $1 \mathbf{r}$ & \multicolumn{2}{|c|}{$\begin{array}{c}\text { 2-Methoxy-2- } \\
\text { phenylacetophenone }\end{array}$} & $r$ & 10 & $2 \mathbf{r}$ & 88 \\
\hline
\end{tabular}

" 5 mol\% of $\mathrm{GaCl}$ : was used. Inseparable many products were obtained $28 \%$ of (1-Methy l)-m-nitrobence] ether was obtained. $"(\%) \%$ of (IMethọl)-p-nitrobeņ̣̃l elher was oblained. 


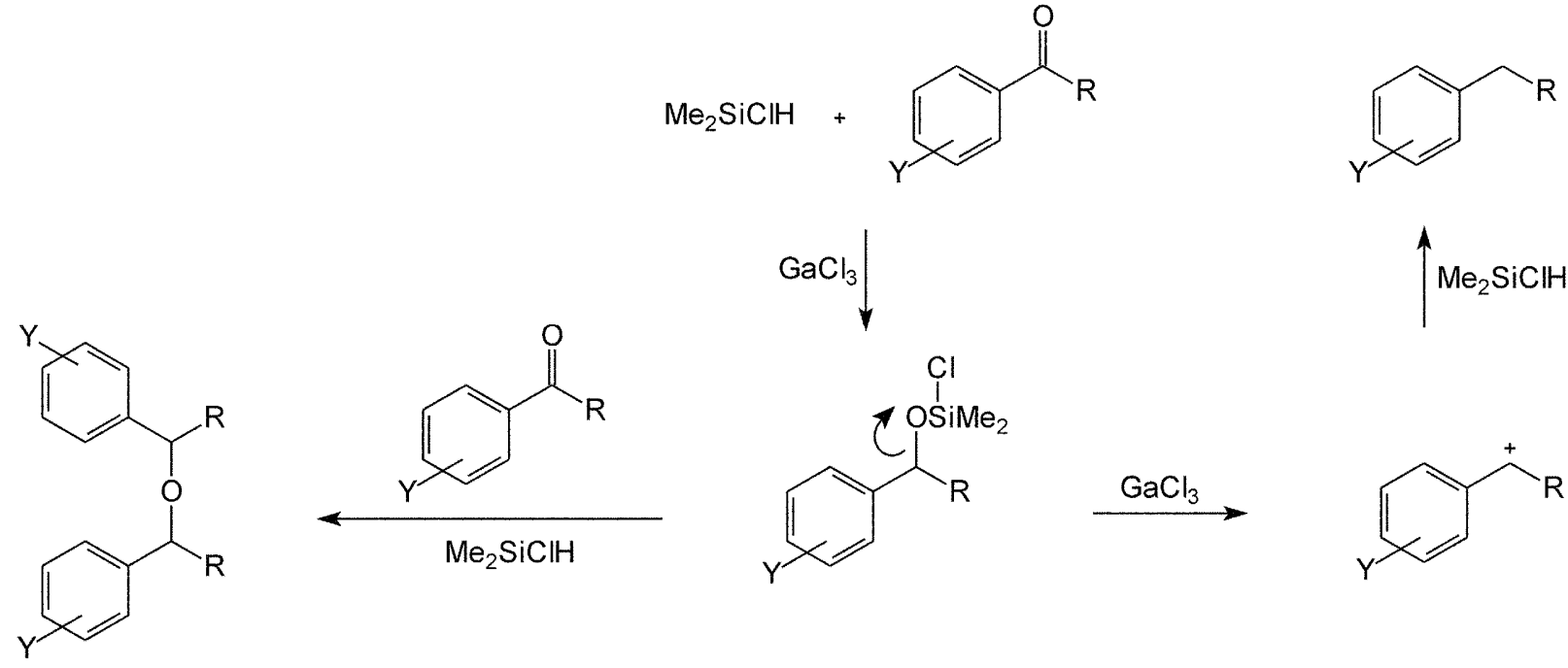

Scheme 1

methylsilane.

In this study, we found that the combination of gallium(IIJ) chloride and chlorodimethylsilane is more effective for the deoxygenation of aryl ketones to the corresponding metlylene compounds than the combination of indium(III) chloride and chlorodimethylsilane. In most cases, the reaction was over within $10 \mathrm{~min}$ and the direct deoxygenation by using galliun(III) chloride proceeded faster than using indium(IIl) chloride. Direct deoxygenation using indium(III) chloride for the aryl ketones took at least I hour for the completion of the reaction. "Furthermore, aryl ketones were deoxygenated to the corresponding hydrocarbons by using lower concentrations of gallium(III) chloride ( $1-5 \mathrm{~mol} \%$ ) than those of indium(III) chloride (5-10 mol\%). Thus, we assumed that gallium(III) chloride was more effective and powerful in producing a carbocation intermediate from an alcohol than indium(III) chloride.

The reduction of acetophenone (1 a), propiophenone (1 b), butyrophenone (1c), and isobutyrophenone (1d) provided the corresponding methylenes (2a-d) in good yields (run 14). However, the yields of isolated metlylene compounds were inversely proportional to the lengh of the acyl side chain of aryl ketones.

The relatively slow reaction rates for benzophenone (le, run 5) and $p$-methoxy-acetophenone (lh, run 8) were observed. It was considered that the resonance effects with two phenyl groups of $1 \mathbf{e}$ and the presence of parasubstituted electron-donating group of $\mathbf{l} \mathbf{h}$ appeared to hinder the reduction by increasing the electron density of carbonyl group. On the other hand, $m$ - or $p$-nitroacetophenone ( $1 \mathbf{i}$ and 1 j, run 9 and 10) was reduced to the corresponding hydrocarbon with poor yields and inseparable by-products due to the decomposition of unstable intermediate. Furthermore, from the reduction of $\mathbf{1 i}$ and $\mathbf{1} \mathbf{j}$, the corresponding dimerized ethers, (1-methyl)-m-nitrobenzyl ether and ( 1 metlyl)-p-nitrobenzyl ether were isolated in $28 \%$ and $9 \%$ yield, respectively. It was assumed that the formation of carbocation was difficult by electron-withdrawing character of the nitro group.

${ }^{m}$ - or $p$-Aminoacetophenone (1 $\mathbf{k}$ and $\mathbf{1} \mathbf{m}$, run $1 /$ and 12$)$ provided no reaction under the conditions mentioned above because of the formation of the complex between gallium(III) chloride and amino group.

In conclusion. we have found that the direct deoxygenation of aryl ketone using $\mathrm{GaCl}_{3}$ as a I.cwis acid and chlorodimethylsilane as a hydride donor proceeded effectively under mild conditions.

Acknowledgements. This work was supported by the research find of Hanyang University (HY-2002-I).

\section{References}

I. (a) Vedejs, E. Org. React 1975, 22, 401: (b) Martin, E. L. Org Reckt. 1942, I, 155 .

2. Todd, D. Oig React 1948, 4,378

3. Blackwell, J.; Hickinboltom, W. J. J. ( hem. Soc. 1961, 1405.

4. Gribble, G W.; Kelly, W. J.: Fmery, S. F. Symhesis 1978, 763

5. Fry, J. L.; Orfanopoulos. M.: Adlington, M. Ci; Dittman, W. P.; Silverman, S. B. J. Ong ( hem. 1978, +3. 374 .

6. West, C. T.; Donnelly, S. J.; Koistra. D. A.; Doyle. M. P. J. Org (hem. 1973, 38, 2675.

7. Kursanov, D. N.; Parnes, $Z$. N.; Loim. N. M. Symhesis 1974 , 633

8. Reimschneider, R.; Kassahn, H. (Wem, Ber: 1959, 92, 1705

9. Ilicks, L. D.: I Ian, J. K: Fry, A. J. Tetwatedon Lett. 2000, H, 7817.

10. Augustine, R. L. ("atalytic Hybhrgenation; Dekker: New York, 1965 .

1]. 'Takashi, M.; Masako, U.: Baba, A. Synte"l 1999, 2, 182

12. Miyai, T.; Onishi, Y.; Baba, A. Tetrahedron /.ett. 1998, 39.6291.

13. Kobayashi, K.; Arisawa, M.; Yamaguchi, M. Inorg. Chim. Acta $1999,296,67$

14. Hashimoto, Y : Hirata, K.; Kagoshuma, H.: Kihara, N.; Hasegawa, M.: Saigo, K. Tetwahedron 1993, 19, 5969 